\title{
Novel Pseudomonas Product Stimulates Interleukin-8 Production in Airway Epithelial Cells In Vitro
}

\author{
Pierre P. Massion, Hiromasa Inoue, Janice Richman-Eisenstat, Dorit Grunberger, Philippe G. Jorens, \\ Bruno Housset, Jean-François Pittet, ${ }^{5}$ Jeanine P. Wiener-Kronish, ${ }^{\star 3}$ and Jay A. Nadel ${ }^{\star *}$ \\ Cardiovascular Research Institute and Departments of * Medicine and ${ }^{\ddagger}$ Physiology, \\ and ${ }^{\S}$ Anesthesiology, University of California, San Francisco, California 94143
}

\begin{abstract}
Because high concentrations of IL-8 are found in the sputum of cystic fibrosis patients, we hypothesized that Pseudomonas aeruginosa (PA) induces the production of IL-8 in airway epithelial cells and in monocytes. Therefore, we incubated the supernatant from PA culture with human transformed bronchial epithelial cells (16-HBE) or with monocytes. The culture medium of 16-HBE cells that had been incubated with PA supernatant for $6 \mathrm{~h}$ had chemotactic activity that was inhibited by an antibody to human IL-8. The PA supernatant induced IL-8 production by primary bronchial epithelial cells, by 16-HBE cells, and by monocytes. After incubation with PA supernatant, 16-HBE cells showed a marked increase in the levels of IL-8 gene expression. The PA product responsible for IL-8 production resisted freezing, boiling, and proteolysis. This product was not lipid extractable and was present in a 1-kD filtrate. We conclude that a small molecular mass product of PA stimulates IL-8 production by 16-HBE cells and by monocytes, and that the chemotactic activity produced by 16-HBE cells after exposure to PA is due principally to IL-8. ( J. Clin. Invest. 1994. 93:26-32.) Key words: epithelium • cytokine expression • cystic fibrosis • endotoxin • chemotaxis
\end{abstract}

\section{Introduction}

Polymorphonuclear neutrophil influx and chronic bacterial infection in the airways are two major characteristics of cystic fibrosis $(\mathrm{CF})^{1}(1,2)$. Accumulation of large numbers of neutrophils is incriminated in tissue damage and in airway gland hypersecretion associated with various airway diseases $(3,4)$. Moreover, abnormal airway secretions may lead to airway obstruction and death. Therefore, the cause of this neutrophil influx has important pathophysiologic implications. We hypothesized that chemotactic factors may be secreted by bacteria or by host cells in patients with chronic airway infection. Among the chemotactic factors for neutrophils produced by

This work has been presented in abstract form (Clin. Res. 1993. 41:55 [Abstr.] and Am. Rev. Respir. Dis. 1993. 147:400[Abstr.].

Address correspondence to Dr. Jay A. Nadel, Cardiovascular Research Institute, Box 0130, University of California, San Francisco, San Francisco, CA 94143-0130.

Received for publication 20 April 1993 and in revised form 29 July 1993.

1. Abbreviations used in this paper: CF, cystic fibrosis; PA, Pseudomonas aeruginosa; TSBD, trypticone soy broth dialysate.

J. Clin. Invest.

(c) The American Society for Clinical Investigation, Inc.

0021-9738/94/01/0026/07 \$2.00

Volume 93, January 1994, 26-32 the airways, IL- 8 is one of the most potent (5-7). Because high concentrations of IL- 8 are found in the sputum of CF patients (8) and because Pseudomonas aeruginosa (PA) is the predominant infecting microorganism found in the airways of CF patients, we examined the effect of PA on production of IL-8 by two types of cells that express IL-8 in humans: airway epithelial cells and blood monocytes. We also partially characterized the PA product responsible for increasing IL-8 expression in airway epithelial cells.

\section{Methods}

Culture media, cytokines, antibodies, and other reagents. Medium 9, MEM, MEM Eagles with Earle's balanced salt solution, DME, Ham's F-12, FCS, PBS, HBSS, penicillin-streptomycin, and trypticone soy broth dialysate (TSBD) were obtained from the Cell Culture Facility, University of California, San Francisco; Ultroser G serum substitute was obtained from IBF Biotechnics (Savage, MD); IL-8 ELISA kit was purchased from R \& D System (Minneapolis, MN); human fibronectin was purchased from Collaborative Research (Bedford, MA); BSA, FMLP, Pseudomonas LPS, SSC, SDS, trypsin type IX, and pronase type XIV were purchased from Sigma Chemical Co. (St. Louis, MO); pronase $(50,000 \mathrm{U})$ was purchased from Calbiochem Behring Corp. (La Jolla, CA); Vitrogen 100 was purchased from Celtrix Lab. (Palo Alto, CA); IL- $1 \beta$ and TNF- $\alpha$ were purchased from Genzyme Co. (Cambridge, MA); human recombinant IL-8 and F( $\left.\mathrm{ab}^{\prime}\right)_{2}$ fragments of IL-8 and gp120 antibodies were provided by Dr. Caroline Hébert (Genentech, Inc., South San Francisco, CA), and human transformed bronchial epithelial cells (16-HBE cells; characterized previously [9]) were provided by Dr. Dieter Gruenert (University of California, San Francisco).

Cell culture. 16-HBE cells were grown to confluence in MEM supplemented with $10 \%$ FCS and $100 \mathrm{U} / \mathrm{ml}$ each of penicillin and streptomycin on 35-mm plates coated with fibronectin and collagen.

Human primary cultured bronchial airway epithelial cells were isolated from donor lung without known history of pulmonary disease at the time of lung transplantation. Briefly, the epithelium was stripped off the mucosa, rinsed in PBS, and incubated at $4^{\circ} \mathrm{C}$ overnight in pronase $(0.4 \mathrm{mg} / \mathrm{ml})$. Sheets of cells were dislodged by vigorous agitation. Isolated cells were pelleted and resuspended in 1:1 mixture of DME and Ham's F-12 containing 5\% FCS. The cells were plated at $5 \times 10^{5}$ viable cells $/ \mathrm{cm}^{2}$ onto tissue culture dishes coated with fibronectin and collagen. On the first day after plating, the culture medium was replaced by serum-free DME/F12 containing $2 \%$ Ultroser G serum substitute. All studies were carried out when the cells were confluent.

PA strain PA1O3 was selected because it is highly toxic and well characterized (10). The bacteria were grown in TSBD (11) for $72 \mathrm{~h}$ at $37^{\circ} \mathrm{C}$. A cell-free supernatant was obtained by centrifugation at 10,000 rpm for 60 min at $4^{\circ} \mathrm{C}$ and by filtration through a $0.22-\mu \mathrm{m}$ filter (Corning, Inc., Corning, NY). The supernatant was aliquoted and stored at $-70^{\circ} \mathrm{C}$ until used. We also cultured and studied a cell-free supernatant of six strains of PA ( three mucoid, three nonmucoid), and one strain of Pseudomonas cepacia. All specimens were freshly isolated from the sputum of CF patients. Supernatants from these strains were prepared in the same manner as the supernatant from the PA1O3 strain. 
Incubation conditions. The 16-HBE cells were studied when they reached confluence. Before the incubation period, 16- HBE cells were washed twice with PBS at $37^{\circ} \mathrm{C}$. The cells were incubated with PAIO3 bacteria or with PA1O3 supernatant for periods up to $6 \mathrm{~h}$. The culture medium of 16-HBE cells was examined for IL-8 activity using an ELISA. Epithelial cells were then scraped with a plastic spatula, resuspended in $1 \mathrm{ml} \mathrm{PBS}$ at $4^{\circ} \mathrm{C}$, and sonicated for $10 \mathrm{~s}$ (minimum setting, Branson, model 350; Sonifier Inc., Danbury, CT). As a reflection of the cell number, the cell fraction was assayed for DNA content by a fluorometric method (12). Lactic dehydrogenase release was measured immediately to assess cell viability (LDH 320 ; Sigma Chemical Co.) and never exceeded 5\% release under the experimental conditions. Primary cells were incubated with PA1O3 supernatant diluted 1:4 for $6 \mathrm{~h}$ in four separate experiments.

Neutrophil and monocyte isolation. Human monocytes and neutrophils were isolated from the blood of healthy volunteers. EDTA-anticoagulated blood was diluted 1:2 with $\mathrm{Ca}^{2+}$ - and $\mathrm{Mg}^{2+}$-free HBSS, layered on top of Histopaque 1077 (Sigma Chemical Co.), and centrifuged at $400 \mathrm{~g}$ for $20 \mathrm{~min}$ at $20^{\circ} \mathrm{C}$. The monocyte-rich fraction was aspirated and centrifuged at $200 \mathrm{~g}$ for $2 \mathrm{~min}$ to remove platelets. The cells were washed with $\mathrm{Ca}^{2+}$ - and $\mathrm{Mg}^{2+}$-free HBSS, resuspended in MEM Eagle's with Earle's BSS, and counted by hemocytometry. The cells were plated at a density of $10^{6}$ monocytes $/ 2 \mathrm{ml}$ and were allowed to adhere to plastic for $30 \mathrm{~min}$ at $37^{\circ} \mathrm{C}$. The nonadherent cells were washed away three times with Eagle's MEM with Earle's BSS. The remaining monocytes were then incubated with MEM containing various stimuli. Red blood cells were removed from the neutrophil-rich pellet by hypotonic lysis. The neutrophils were washed and resuspended in $\mathrm{Ca}^{2+}$ - and $\mathrm{Mg}^{2+}$-free $\mathrm{HBSS}$ with $2 \%$ BSA. These neutrophils were further diluted with $\mathrm{Ca}^{2+}$ - and $\mathrm{Mg}^{2+}$-containing $\mathrm{HBSS}$ with $2 \%$ BSA to a cell density of $4 \times 10^{6}$ cells $/ \mathrm{ml}$. The neutrophil suspension was at least $96 \%$ pure and was $99 \%$ viable as determined by trypan blue dye exclusion.

Neutrophil chemotaxis assay. The chemotactic activity of PA1O3 supernatant and of the culture medium of 16-HBE cells collected $6 \mathrm{~h}$ after incubation with increasing concentrations of $\mathrm{PA} 1 \mathrm{O} 3$ supernatant was assessed in a 48-well microchemotaxis chamber ( Neuroprobe, Cabin John, MD) using human neutrophils isolated from healthy volunteers (13). The chemotactic activity was assayed by the leading front technique (14). Neutrophils were allowed to migrate through a nitrocellulose filter of $3-\mu \mathrm{m}$ pore size for $25 \mathrm{~min}$ at $37^{\circ} \mathrm{C}$. The results are expressed as net neutropil migration (migration to sample minus migration to culture medium alone).

To determine whether PAIO3 supernatant was chemotactic, we diluted the supernatant with the bacterial culture medium (TSBD), measured neutrophil migration towards dilutions of the bacterial culture supernatant, and subtracted the migration towards TSBD alone. To determine whether 16-HBE cells exposed to PA1O3 supernatant produced chemotactic activity for neutrophils, we measured neutrophil migration towards the culture medium of 16-HBE cells exposed for $6 \mathrm{~h}$ to varying concentrations of PA1O3 supernatant (1:2.6-64). For each experiment, we used positive controls of neutrophil migration consisting of human monocyte-derived recombinant IL-8 $\left(10^{-11}\right.$ to $10^{-8} \mathrm{M}$ ) diluted in MEM.

We performed studies to determine the extent to which IL-8 is responsible for the chemotactic activity produced by $16-\mathrm{HBE}$ cells exposed to PA1O3 supernatant (diluted 1:4). The culture medium of these $16-\mathrm{HBE}$ cells was incubated for $30 \mathrm{~min}$ at $37^{\circ} \mathrm{C}$ with $\mathrm{F}\left(\mathrm{ab}^{\prime}\right)_{2}$ fragments $(0.01,0.1,1$, and $10 \mu \mathrm{g} / \mathrm{ml})$ of a mouse monoclonal antihuman blocking IL-8 antibody. $\mathrm{F}\left(\mathrm{ab}^{\prime}\right)_{2}$ fragments $(10 \mu \mathrm{g} / \mathrm{ml})$ of a monoclonal antibody to gpl 20 , an HIV protein, were used as a negative control, or with the same volume of buffer $\left(\mathrm{Ca}^{2+}\right.$ - and $\mathrm{Mg}^{2+}$-containing HBSS ). The $\mathrm{F}\left(\mathrm{ab}^{\prime}\right)_{2}$ fragments alone were not chemotactic.

IL-8 expression. IL-8 mRNA was analyzed by Northern blotting. Total RNA was extracted from 16-HBE cells that had been cultured to confluence. $3 \mathrm{~h}$ after incubation, the cells were washed twice with PBS and scraped from the dish. The RNA was extracted with RNA Stat-60 solution (Tel-test "B", Inc.. Friendwood, TX), ethanol precipitated. washed twice with $70 \%$ ethanol, dried, and resuspended in water. Aliquots of $20 \mu \mathrm{g}$ total RNA (determined by spectrophotometry, $260 \mathrm{~nm}$ wavelength) were denatured and run on a denaturing formaldehyde $1 \%$ agarose gel. RNA markers were run in parallel for determination of molecular size. The RNA was transferred to a nylon membrane (Genescreen; DuPont, New England Nuclear, Boston, MA) and UV crosslinked to the membrane.

We obtained a pUC19-derived plasmid containing a human IL-8 cDNA insert of 478 bp from Genentech. Inc. (South San Francisco, CA). The insert, consisting of $384 \mathrm{bp}$ of the IL- 8 coding and $94 \mathrm{bp}$ of the plasmidic sequence, was isolated after digestion with the restriction enzyme EcoRI, and labeled with $\left[{ }^{32} \mathrm{P}\right] \mathrm{dCTP}$ by random priming (GIBCO-BRL, Gaithersburg, MD). Unincorporated label was separated by column chromatography (Nuct Trap; Strategene, La Jolla. CA). The yield was $60-80 \%$ incorporation of label with a specific activity of $10^{8} \mathrm{cpm} / \mu \mathrm{g}$ DNA. Filters were prehybridized overnight at $42^{\circ} \mathrm{C}$ in fresh prehybridization buffer supplemented with $10 \%$ dextran sulfate and hybridized at $50^{\circ} \mathrm{C}$ with the denatured ${ }^{32} \mathrm{P}$-labeled cDNA probe. Blots were washed twice for $30 \mathrm{~min}$ at $50^{\circ} \mathrm{C}$ in $0.5 \times \mathrm{SSC} / 1 \%$ SDS. To assess the relative amounts of RNA loaded, all blots were rehybridized for $\gamma$-actin after stripping of the original probe. Densitometry (GS 300 Transmittance/Reflectance Scanning Densitometer; Hoefer Scientific Instruments, San Francisco, CA) was used to quantify IL-8 RNA expression.

Partial characterization of the PAIO3 product that stimulates IL-8 production. For the characterization of the Pseudomonas product responsible for IL-8 production in 16-HBE cells, we cultured $200 \mathrm{ml}$ of PA1O3 for $72 \mathrm{~h}$ at $37^{\circ} \mathrm{C}$ in $\mathrm{M} 9$ culture medium (supplemented with succinic acid [ $15 \mathrm{~g}$ /liter]. $0.2 \%$ glucose, $2 \mathrm{mM} \mathrm{MgSO}_{4}, 100 \mathrm{mM} \mathrm{CaCl}$. and $100 \mathrm{mM} \mathrm{L-glutamic} \mathrm{acid)} \mathrm{under} \mathrm{shaking} \mathrm{conditions} \mathrm{(} 150 \mathrm{rpm})$. The ability of PA to increase IL-8 production in $16-\mathrm{HBE}$ cells was tested for stability by freezing to $-80^{\circ} \mathrm{C}$ or boiling for $60 \mathrm{~min}$ and then incubating for $6 \mathrm{~h}$ with $16-\mathrm{HBE}$ cells.

The supernatant was fractionated by molecular mass using Amicon YM-30, 10. 3, and 1 membranes (62-mm diameter; Amicon, Beverly, MA), which yielded filtrates with molecular masses smaller than 30 , 10,3 , and $1 \mathrm{kD}$, respectively. The $1-\mathrm{kD}$ filtrates were then subjected to proteolytic digestion for $120 \mathrm{~min}$ at $37^{\circ} \mathrm{C}$ with trypsin $(40 \mu \mathrm{g} / \mathrm{ml})$ or pronase $(2 \mathrm{mg} / \mathrm{ml})$, and subsequently boiled for $10 \mathrm{~min}$ to inactivate the enzymes. The filtrates were then incubated with 16-HBE cells. To assess whether the factor inducing IL-8 is lipophilic, we extracted the PA1O3 supernatant with $2.5 \mathrm{vol}$ of methanol and 1.5 vol of chloroform. The organic phase was dried down under $\mathrm{N}_{2}$ and dissolved in PBS. Both aqueous and organic phases were tested for IL-8 production by $16-\mathrm{HBE}$ cells $6 \mathrm{~h}$ after incubation. Because PA secretes FMLP-like peptides $(15)$, we tested the ability of FMLP $\left(10^{-6} \mathrm{M}\right)$ to stimulate IL-8 production in 16-HBE cells.

Statistical analysis. All data are presented as means \pm SEM. Measurements at different time points after incubation were compared by analysis of variance (ANOVA). The significance of differences between values was assessed using Scheffe's multiple comparison test. $P$ values $<0.05$ were considered to indicate statistical significance.

\section{Results}

Production of neutrophil chemotactic activity by airway epithelial cells after incubation with PA supernatant. The PA1O3 supernatant was not significantly chemotactic for human neutrophils at any of the dilutions tested (1:1-1,000) (Fig. 1). When the culture medium collected from the 16-HBE cells was incubated for $6 \mathrm{~h}$ with TSBD diluted 1:4, there was slight neutrophil chemotactic activity (net neutrophil migration, $11.3 \pm 1.9 \mu \mathrm{m} ; n=5$ ). In contrast, after incubation for $6 \mathrm{~h}$ with increasing concentrations of PA supernatant, neutrophil chemotactic activity in the 16-HBE cells had increased significantly, an effect that occurred in a concentration-dependent manner (Fig. 2). 
Net Neutrophil Migration $(\mu \mathrm{m})$

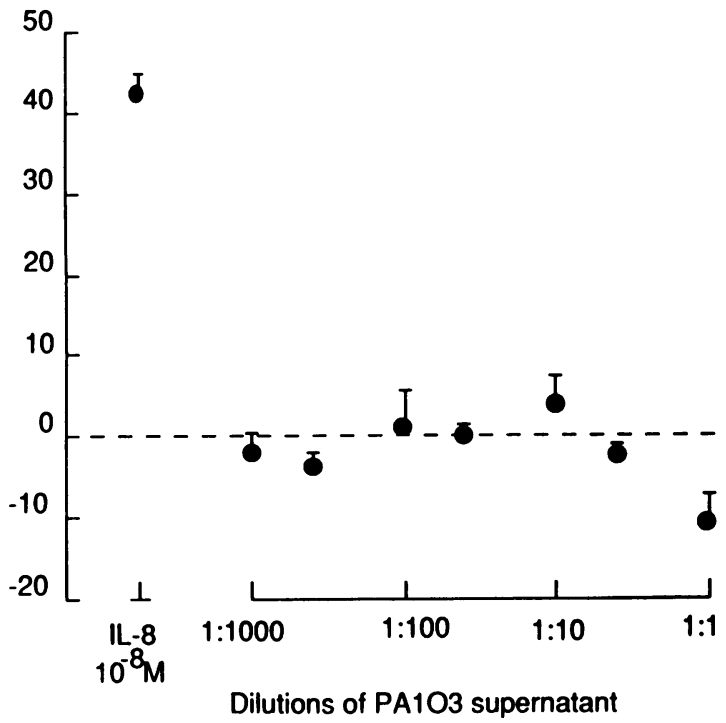

Figure 1. Effect of various dilutions of PA culture supernatant (PA1O3 strain) on chemotactic activity of human neutrophils. Random migration obtained from control, TSBD (the culture medium of Pseudomonas), or HBSS (the suspension buffer for IL-8) is subtracted from each sample. The effect of PA supernatant is compared with the effect of human recombinant IL- $8\left(10^{-8} \mathrm{M}\right)$ on neutrophil migration. PA supernatant alone was not chemotactic at any dilution. Each point represents net neutrophil migration. Values are means \pm SEM; $n=4-6$.

We examined the role of IL-8 in the chemotactic activity produced by incubating the human airway cells with Pseudomonas supernatant. We measured IL-8 concentrations in the cell culture medium, and we found significant amounts of IL8 ; the chemotactic activity of the medium was comparable to the activity found in similar concentrations of recombinant human IL-8 (Fig. 3). These studies suggest that the neutrophil chemoattractant produced by the coincubation of PA1O3 bacteria and human airway epithelial cells (16-HBE) is IL-8. We confirmed these findings by incubating culture medium of 16HBE cells exposed for $6 \mathrm{~h}$ to PA1O3 supernatant (diluted 1:4) with a monoclonal blocking antibody to human IL-8 and subsequently measuring the neutrophil chemotactic activity. Addition of the IL-8 blocking antibody inhibited the neutrophil chemotactic activity. Addition of the IL-8 blocking antibody inhibited the neutrophil chemotactic activity in a dose-dependent manner (Fig. 4). In a separate experiment, incubation with the $\mathrm{F}\left(\mathrm{ab}^{\prime}\right)_{2}$ fragments $(10 \mu \mathrm{g} / \mathrm{ml})$ of the gp 120 antibody used as a control antibody had no inhibitory effect on neutrophil migration $(20.38 \pm 1.38$ vs. $18.28 \pm 2.35 \mu \mathrm{m}$ without gp 120 antibody; $4.05 \pm 1.33 \mu \mathrm{m}$ with IL-8 antibody; $n=4$ ).

Time- and concentration-dependent production of $I L-8$ by airway epithelial cells. Because an IL-8 blocking antibody inhibited the neutrophil chemotactic activity present in the medium of 16-HBE cells incubated with PA supernatant, we characterized the induction of IL-8 by $16-\mathrm{HBE}$ cells after exposure to PA1O3 $\left(10^{8}\right.$ bacteria $\left./ \mathrm{ml}\right)$ over a 6 -h period. In the control state, incubation of 16-HBE cells with culture medium alone induced a small amount of IL-8 production. However, incubation of 16-HBE cells with PA1O3 bacteria increased IL-8 production dramatically in a time-dependent manner (Fig. 5).
Net Neutrophil Migration $(\mu \mathrm{m})$

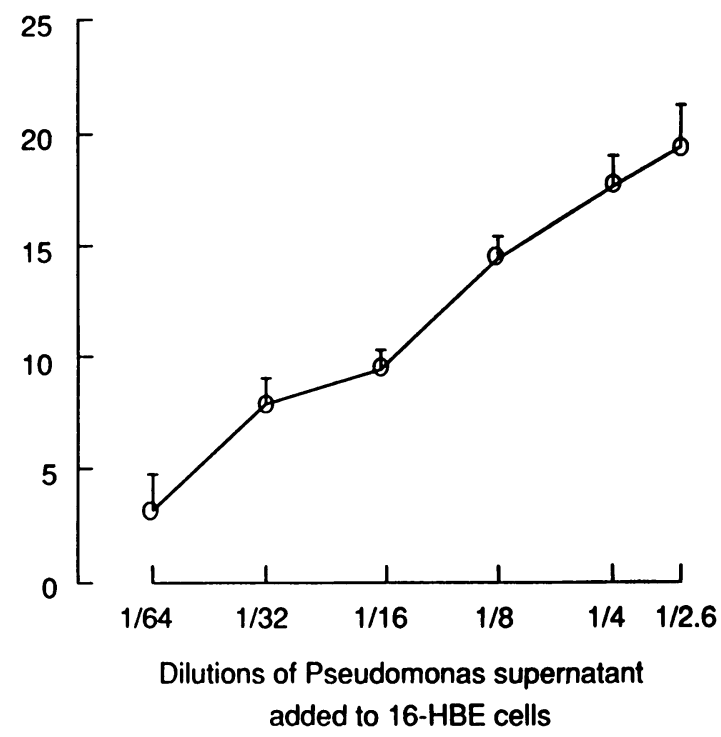

Figure 2. Effect of culture medium of 16-HBE cells obtained $6 \mathrm{~h}$ after incubation with serial dilutions of PA culture supernatant (PA1O3 strain) on chemotactic activity of human neutrophils. Increasing concentrations of the PA supernatant produced a concentration-dependent increase in neutrophil migration. The DNA concentration in the undiluted Pseudomonas supernatant liquid culture was $160 \mu \mathrm{g}$ $\mathrm{DNA} / \mathrm{ml}$. Values are means $\pm \mathrm{SEM} ; n=4$.

Moreover, when studied after $6 \mathrm{~h}$ of incubation of $16-\mathrm{HBE}$ cells with cell-free supernatant of PA1O3, IL-8 production increased in a concentration-dependent manner (Fig. 6). The increase in IL-8 production of $16-\mathrm{HBE}$ cells induced by PA1O3 supernatant reached a maximum $6 \mathrm{~h}$ after incubation and then

Net Neutrophil Migration ( $\mu \mathrm{m})$

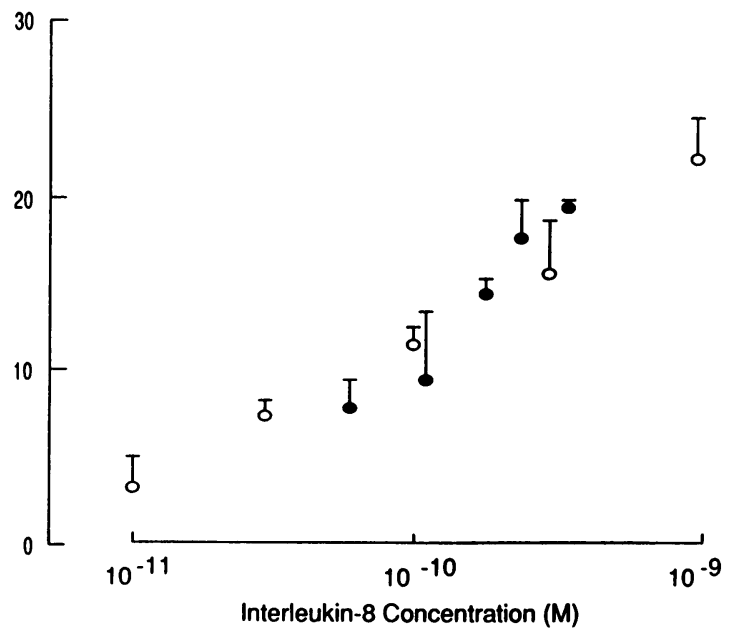

Figure 3. Correlation between chemotactic activity and IL-8 concentrations in the culture medium of $16-\mathrm{HBE}$ cells. Neutrophil chemotactic activity of culture medium of 16-HBE cells obtained $6 \mathrm{~h}$ after incubation with serial dilutions of PA supernatant (PA1O3 strain; filled circles). Data are plotted according to the concentrations of IL-8 in the culture medium and compared with the chemotactic activity of human recombinant IL-8 (open circles). IL-8 accounts for the chemotactic properties of the culture medium. Values are means \pm SEM; $n=4$. 
Net Neutrophil Migration $(\mu \mathrm{m})$

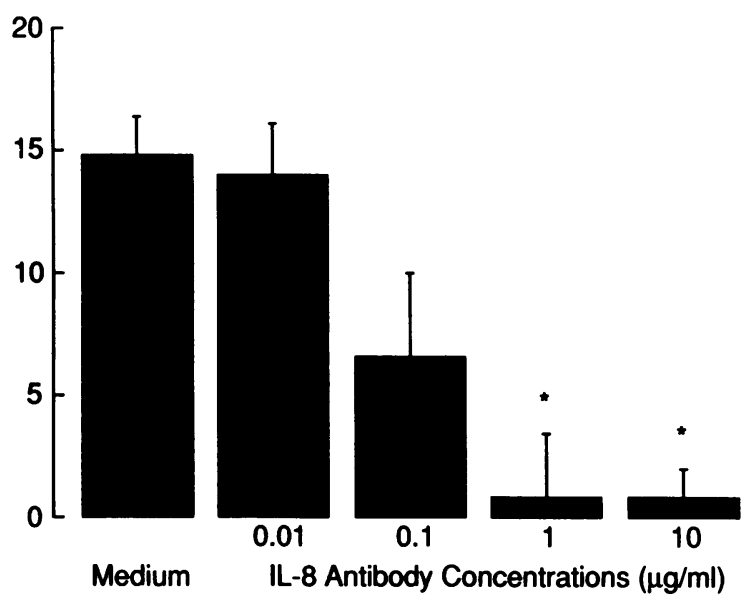

Figure 4. Effect of $\mathrm{F}\left(\mathrm{ab}^{\prime}\right)_{2}$ fragments of a monoclonal anti-human IL-8 blocking antibody on chemotaxis of human neutrophils by the culture medium of 16-HBE cells incubated with PA supernatant (PA1O3 strain, diluted 1:4) for $6 \mathrm{~h}$. The IL-8 blocking antibody prevented the neutrophil chemotaxis due to Pseudomonas supernatant in a dose-dependent manner. Values are means \pm SEM $; n=4$; ${ }^{*}$ Statistically different from medium alone $(P<0.05)$.

remained relatively constant over a period of $6 \mathrm{~d}$ after plating (data not shown).

PA1O3 supernatant also stimulated IL-8 production by primary human bronchial epithelial cells. After $6 \mathrm{~h}$ of incubation, the IL-8 concentration in the culture medium was $133 \pm 14 \mathrm{pg}$ / $\mu \mathrm{g}$ of DNA in the 16-HBE cells in the control condition (TSBD diluted 1:4), and $2271 \pm 58 \mathrm{pg} / \mu \mathrm{g}$ after incubation with a 1:4 dilution of the PA1O3 supernatant $(n=4 ; P<0.001)$.

Effect of various stimuli on $I L-8$ production by human airway epithelial cells and by monocytes. We compared the ability of PA1O3 supernatant, IL- $1 \beta$, TNF- $\alpha$, and Pseudomonas LPS to stimulate IL- 8 production by $16-\mathrm{HBE}$ cells and by human

Interleukin-8

(pg/ $\mu \mathrm{g}$ DNA of $16-\mathrm{HBE}$ cells)

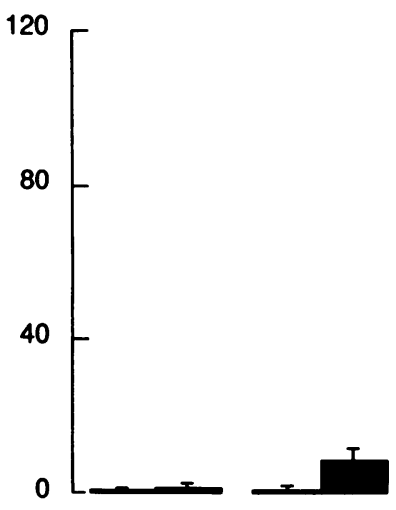

$1 \mathrm{~h}$
$2 \mathrm{~h}$

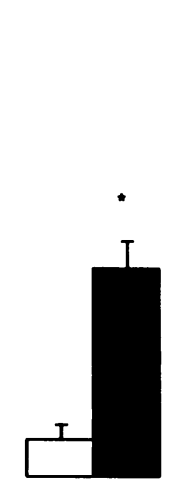

$4 h$

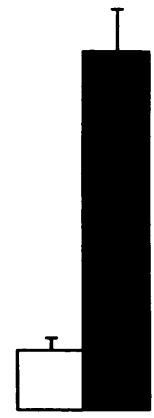

$6 \mathrm{~h}$
Figure 5. Time-dependent IL-8 production by cultured 16-HBE cells after incubation with culture medium, TSBD (open columns), or PA aeruginosa (PAlO3 strain, $10^{8}$ bacteria $/ \mathrm{ml}$; shaded columns). The production of IL-8 was markedly increased by addition of bacteria. Values are means \pm SEM; at each time point, $n=6$; *Statistically different from the control state at the same time $(P<0.05)$.
Interleukin-8

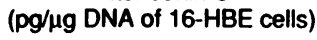

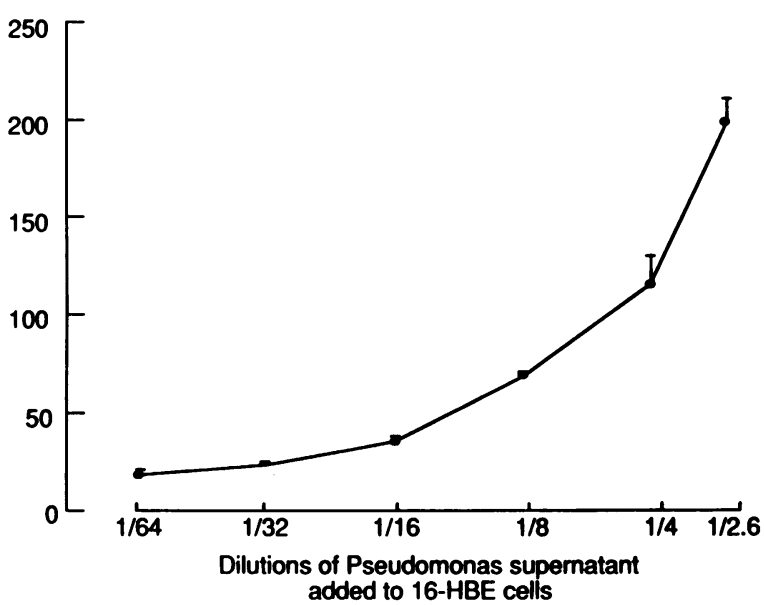

Figure 6. Effect of $6 \mathrm{~h}$ of incubation of various dilutions of PA supernatant (PA1O3 strain) on IL-8 production by 16-HBE cells. IL-8 is expressed as picograms per micrograms DNA of 16-HBE cells. Incubation of the airway epithelial cells with PA supernatant increased IL-8 production in a concentration-dependent manner. Values are means \pm SEM; $n=6$.

blood monocytes. The increase by IL-8 production of 16-HBE cells that had been stimulated with PA1O3 supernatant diluted $1: 4$ was greater than the increase after stimulation with IL- $1 \beta$ or TNF- $\alpha$ used at $20 \mathrm{ng} / \mathrm{ml}$ (the concentration that we found to maximally stimulate IL-8 production in 16-HBE cells; data not shown ). Pseudomonas LPS $(1 \mu \mathrm{g} / \mathrm{ml})$ induced IL-8 production by monocytes but not by $16-\mathrm{HBE}$ cells. Peripheral blood monocytes followed the same pattern of stimulation with PA1O3, IL-1 $\beta$, and TNF- $\alpha$ (Fig. 7). The supernatant of various strains of Pseudomonas also induced IL-8 production in 16-HBE cells ( Table I).

IL-8 gene expression by human airway epithelial cells. 16HBE cells showed low levels of IL-8 gene expression in the control state, but after incubation with PA1O3 supernatant, 16-HBE cells showed a marked increase in the levels of IL-8 gene expression. The maximal increase in IL-8 gene expression due to PA1O3 supernatant was greater than the increase due to IL- $1 \beta$ and TNF- $\alpha$ (both used at $20 \mathrm{ng} / \mathrm{ml}$ ). Pseudomonas LPS did not stimulate IL-8 expression in 16-HBE cells (Fig. 8).

Partial characterization of the active $P A 1 O 3$ product. The active product of PA1O3 supernatant responsible for stimulating IL-8 production by 16-HBE cells resisted freezing, boiling, and proteolytic digestion. The filtrate of membranes with a 1-kD cut-off retained the ability to induce IL-8 production. The organic phase of the lipid extraction induced very little IL-8 production, whereas the aqueous phase retained most the activity. These results are summarized in Table II. IL- 8 production by 16-HBE cells $6 \mathrm{~h}$ after stimulation with FMLP $(8.5 \pm 2.0$ pg IL-8/ $\mu$ g DNA) was not statistically different from the control condition ( $14 \pm 1.8 \mathrm{pg}$ IL-8/ $\mu \mathrm{g}$ DNA) in four separate experiments.

\section{Discussion}

The influx of neutrophils into the airways is an important characteristic of PA infection in patients with CF. In this study we provide evidence that PA supernatant is indirectly chemotactic 
Interleukin-8

(pg/ $\mu$ gDNA of 16-HBE cells)

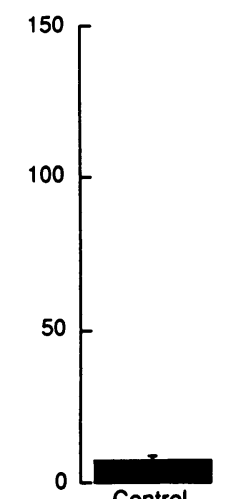

Control
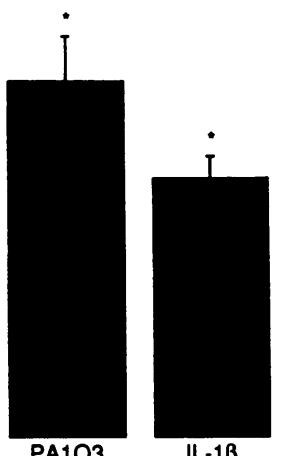

IL-1ß
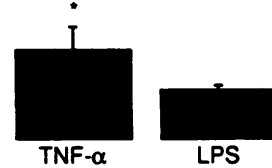

Interleukin-8

(pg/mi /106 monocytes)
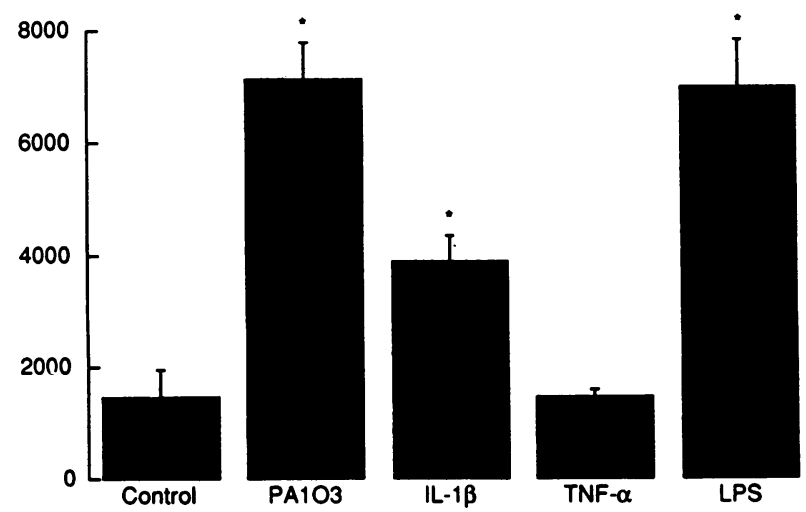

Figure 7. IL-8 production by 16-HBE cells; (top) and by blood monocytes (bottom) $6 \mathrm{~h}$ after incubation with PA supernatant (PA1O3 strain; 1:4 dilution ), IL- $1 \beta(20 \mathrm{ng} / \mathrm{ml}), \mathrm{TNF}-\alpha(20 \mathrm{ng} / \mathrm{ml})$, and Pseudomonas LPS $(1 \mu \mathrm{g} / \mathrm{ml})$. Pseudomonas supernatant was most potent in causing IL-8 production; human monocytes produced more IL- 8 than the epithelial cells. Values are means \pm SEM; $n=3$; *Statistically different from control.

for neutrophils by stimulating the production of IL-8 in human airway epithelial cells and in monocytes. We found that PA supernatant is not chemotactic for neutrophils in our preparation but that the culture medium of bronchial epithelial cells after exposure to PA1O3 is time-dependently chemotactic for human neutrophils and that this chemotactic activity is inhibited by a blocking monoclonal antibody to human IL-8. From these results, we reasoned that PA supernatant stimulates the production of IL- 8 in the cells tested. Because epithelial cells and monocytes are sources of IL- 8 in the airways, we studied the production of IL- 8 by human airway epithelial cells and by human monocytes after stimulation with PA. We found that PA supernatant stimulates IL- 8 expression and production by both cell types.

PA affects neutrophil recruitment into the airways by direct and indirect mechanisms. Bacterial culture supernatants from PA induce neutrophil chemotactic activity directly (15-17). Among many products isolated from PA $(18,19)$, FMLP-like molecules and rhamnolipids $(15,20)$ have been shown to induce direct neutrophil chemotactic activity, but the pathophysiological importance of these chemoattractants is unknown. The direct neutrophil chemotactic activity of PA appears to be
Table I. Effect of Various Pseudomonas Strains Isolated from CF Patients on IL-8 Production by 16-HBE Cells

\begin{tabular}{lc}
\hline \multicolumn{1}{c}{ Experimental condition } & IL-8/DNA of $16-\mathrm{HBE}$ cells \\
\hline & $p g / \mu g$ \\
TSBD (culture medium alone) & $31.4 \pm 7.9$ \\
PA, 103 & $214.0 \pm 33.2$ \\
PA, mucoid & $162.0 \pm 14.2$ \\
PA, mucoid & $338.0 \pm 5.0$ \\
PA, mucoid & $214.2 \pm 11.7$ \\
PA, nonmucoid & $118.8 \pm 14.1$ \\
PA, nonmucoid & $361.7 \pm 36.5$ \\
PA, nonmucoid & $187.1 \pm 32.2$ \\
Pseudomonas cepacia & $71.6 \pm 9.5$ \\
\hline
\end{tabular}

Stimulation of IL- 8 production by $16-\mathrm{HBE}$ cells with various $\mathrm{Pseu}$ domonas strains isolated from CF patients. 16-HBE cells were incubated for $6 \mathrm{~h}$ with a 1:4 dilution of the bacterial-free culture supernatant. Data are expressed as picograms of IL-8/microgram of DNA measured in 16-HBE cells. For each experimental condition, $n=4-8$.

modulated by Pseudomonas LPS, which has been shown to decrease neutrophil migration (2, 21-23). In our study, PA1O3 supernatant did not have direct chemotactic activity. This discrepancy may be due, at least in part, to differences in the Pseudomonas strain or to differences in methodology.
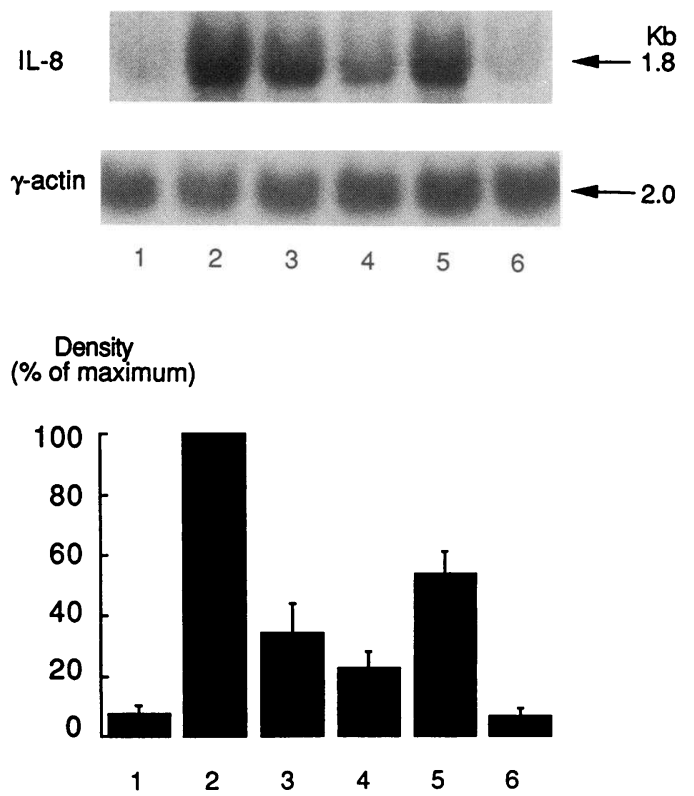

Figure 8 . Northern blot analysis of IL-8 mRNA expression by 16HBE cells after $3 \mathrm{~h}$ of incubation with culture medium alone (lane 1), PA supernatant (PA1O3 strain) at dilutions $1: 4$ and $1: 8$, respectively (lanes 2 and 3$), \mathrm{TNF}-\alpha,(20 \mathrm{ng} / \mathrm{ml})$ (lane 4$), \mathrm{IL}-1 \beta,(20 \mathrm{ng} /$ $\mathrm{ml}$ ) (lane 5), or Pseudomonas LPS ( $1 \mu \mathrm{g} / \mathrm{ml}$ ) (lane 6 ). The blot was probed with IL- 8 cDNA probe and $\gamma$-actin. The data shown on top are derived from one typical experiment. The size of RNA transcripts are indicated in the right margin. (Bottom) Densitometric study of mRNA transcript levels in 16-HBE cells induced by culture medium alone, PA supernatant at dilutions $1: 4$ and $1: 8$, respectively, TNF- $\alpha$, IL- $1 \beta, 20 \mathrm{ng} / \mathrm{ml}$, or Pseudomonas LPS $(1 \mu \mathrm{g} / \mathrm{ml})$. Data from three experiments are reported and expressed as percent of maximum response of Pseudomonas supernatant. Data shown are representative of three experiments. Values are means \pm SEM. 
Table II. Partial Characterization of Pseudomonas Product

\begin{tabular}{lc}
\hline \multicolumn{1}{c}{ Experimental conditions } & IL-8/DNA in $16-\mathrm{HBE}$ cells \\
& $p g / \mu g$ \\
Control & $14.3 \pm 1.8$ \\
PA103 diluted $1: 4$ & $170.0 \pm 16.3$ \\
Stability & \\
Freezing & $200.2 \pm 23.3$ \\
Boiling & $188.3 \pm 16.3$ \\
Proteolytic digestion $1 \mathrm{hr}, 37^{\circ} \mathrm{C}$ & \\
Pronase & $147.3 \pm 30.8$ \\
Trypsin & $158.1 \pm 9.2$ \\
Chloroform extraction & \\
Aqueous phase & $140.1 \pm 11.2$ \\
Organic phase & $24.1 \pm 3.4$ \\
Filtration & \\
$100 \mathrm{kD}$ & $148.0 \pm 15.2$ \\
$30 \mathrm{kD}$ & $128.8 \pm 16.2$ \\
$10 \mathrm{kD}$ & $124.9 \pm 20.1$ \\
$3 \mathrm{kD}$ & $95.7 \pm 7.2$ \\
$1 \mathrm{kD}$ & $79.7 \pm 8.7$ \\
\hline
\end{tabular}

Physiochemical characteristics of Pseudomonas product that stimulates IL-8 production in airway epithelial cells and in monocytes. 16-HBE cells were incubated for $6 \mathrm{~h}$ with a 1:4 dilution of a sample under each experimental condition. Data are expressed as picograms of IL-8/microgram of DNA measured in 16-HBE cells. For each experimental condition, $n=3-9$.

PA can also induce chemotactic activity indirectly. By activating the complement system, Gram-negative bacteria stimulate the production of C5a, a potent chemotactic factor (24). Gram-negative bacteria also stimulate macrophages to secrete low molecular mass factors (including leukotrienes) that are chemotactic for neutrophils (3). Here we report a new and indirect mechanism by which PA may cause neutrophil recruitment into the airways. We found that PA supernatant stimulates the production of IL-8 in airway epithelial cells and in monocytes. Bacterial adhesion to airway epithelial cells or monocytes is not required for IL-8 expression and secretion, because bacterial culture supernatant alone induced IL- 8 production and mRNA expression in airway epithelial cells.

To identify the PA product(s) responsible for IL-8 induction, we first considered products that have already been characterized. We found that although Pseudomonas LPS stimulates IL-8 production by human peripheral blood monocytes, Pseudomonas LPS does not stimulate IL-8 production by the cultured human airway epithelial cells that we examined. This finding supports previous studies that show that LPS from another bacterium, Escherichia coli, selectively induces IL-8 production by monocytes and by endothelial cells but not by airway epithelial cells or in fibroblasts (28). Because LPS can not explain the stimulation of production of IL- 8 by airway epithelial cells, we attempted to isolate the responsible product.

We separated the PA supernatant by molecular mass, and found that the filtrate of a $1-\mathrm{kD}$ cut-off membrane maintained the ability to induce IL- 8 production in airway epithelial cells. The responsible low molecular mass product was heat stable and was not inactivated by pronase or by trypsin. Its heat stability and lack of protease denaturation suggests that the active product is not a protein. Furthermore, we found that the product that stimulated epithelial cell IL-8 production was not extractable into the lipid fraction. Thus, because of its molecular size and lipid insolubility, the active product is not LPS. The lack of lipid solubility also mitigates against the PA product being a rhamnolipid (25). In addition, the common Pseudomonas exotoxins have much larger molecular masses.

Because of their small molecular mass(es), the PA product (s) would be predicted to penetrate tissues and to induce IL-8 production in cells located both near the lumen (e.g., epithelial cells) and deep in the tissue (e.g., tissue monocytes). In the airways, where the number of monocytes or macrophages may be small, the airway epithelial cells may be the principal sources of IL-8 after Pseudomonas infection. In contrast to airways, macrophages may be a principal source of IL- 8 in the alveolar space (23).

IL-8 gene expression and protein production occurred rapidly after incubation with PA1O3 supernatant: within $3 \mathrm{~h}$ of exposure to PA1O3, airway epithelial cells had already begun to secrete the neutrophil chemoattractant, IL-8. IL-8 production by airway epithelial cells and by monocytes can be stimulated by various cytokines, including IL- $1 \beta$ and TNF- $\alpha$ (2628 ). In this study, the IL- 8 production was greater in response to PA1O3 supernatant diluted $1: 4$ than to IL- $1 \beta$ and to TNF- $\alpha$ used at $20 \mathrm{ng} / \mathrm{ml}$.

Airway infection with PA has been implicated in the pathogenesis of CF (2). Similarly, neutrophils, their products (4), and their DNA (29) may have critical roles in the airway hypersecretion and inflammation that lead to clinical deterioration and death. We suggest that the excessive accumulation of neutrophils in CF airways may be due, at least in part, to IL-8 production. At the interface with the environment, the airway epithelium is positioned to play an important role in host defense. Its close contact with the Pseudomonas bacteria and their secreted products suggests that epithelial cells may play a key role in mobilizing defense mechanisms. We suggest that stimulation of IL-8 production by airway cells exposed to the novel Pseudomonas product (s) described here represents a potentially important cell signaling mechanism for neutrophil recruitment. Abnormalities in this response could play an important role in the pathogenesis of airway obstruction in cystic fibrosis. Antagonists to the PA product(s) might be useful in the therapy of cystic fibrosis.

In summary, we found that a small molecular mass product of PA stimulates IL-8 production by human airway epithelial cells and by monocytes, and we found that the neutrophil chemotactic activity produced by airway epithelial cells after exposure to PA is due principally to IL-8.

\section{Acknowledgments}

We thank Iris Ueki. Ella Highland, Kathleen Grattan, and Richard Shanks for technical assistance, and Natalie Holt and Shauna McDonough for the preparation of the manuscript. We also thank Dr. Dieter Gruenert for providing 16-HBE cells and Dr. Caroline Hébert for providing human recombinant IL-8 and $F\left(a b^{\prime}\right)_{2}$ fragments of IL-8 and gp120 antibodies.

This work was supported in part by National Institutes of Health program research grant HL-24136. Dr. Massion was supported by the Will Rogers Memorial Fund. Dr. Richman-Eisenstat was supported by a fellowship grant from the Medical Research Council of Canada. Dr. Jorens was the recipient of a Rotary Foundation Scholarship. Dr. Housset was supported by a grant from the Philippe foundation and by 
a grant from NATO. Dr. Pittet was supported by a fellowship from the Swiss National Science Foundation (grant 702/90).

\section{References}

1. Hata, J. S., and R. B. Fick, Jr. 1988. Pseudomonas aeruginosa and the airways disease of cystic fibrosis. Clinics in Chest Medicine. 9:679-689.

2. Høiby, N., V. Andersen, and G. Bendixen. 1975. Pseudomonas aeruginosa infection in cystic fibrosis. Acta Pathol. Microbiol. Scand. 83:459-468.

3. Sibille, Y., and H. Y. Reynolds. 1990. Macrophages and polymorphonuclear neutrophils in lung defense and injury. Am. Rev. Respir. Dis. 141:471-501.

4. Nadel, J. A. 1991. Protease actions on airway secretions. Relevance to cystic fibrosis. Ann. NY Acad. Sci. 624:286-296.

5. Mattoli, S., M. Marini, and A. Fasoli. 1992. Expression of the potent inflammatory cytokines, GM-CSF, IL6, and IL8, in bronchial epithelial cells of asthmatic patients. Chest. 101:27S-29S.

6. Nakamura, H., K. Yoshimura, H. A. Jaffe, and R. G. Crystal. 1991. Interleukin-8 gene expression in human bronchial epithelial cells. J. Biol. Chem. 266:19611-19617.

7. Standiford, T. J., S. L. Kunkel, K. R. Gromer, D. Gruenert, H. L. Evanoff, and R. M. Strieter. 1992. Regulation of interleukin-8 gene expression from human tracheal explant-derived epithelial cells by dexamethasone. Am. Rev. Respir. Dis. A 638.

8. Richman-Eisenstat, J. B. Y., P. G. Jorens, I. Ueki, J. Olesch, and J. A. Nadel. 1993. Interleukin-8: an important chemoattractant in sputum of patients with chronic inflammatory airway diseases. Am. J. Physiol.: Lung Cell Mol. Physiol. 264:L413-L418.

9. Cozens, A. L., M. L., Yezzi, K. Kunzelmann, T. Ohrui, L. Chin, K. Eng, W. E. Finkbeiner, J. H. Widdicombe, and D. C. Gruenert. 1994. CFTR expression and chloride secretion in polarized immortal human bronchial epithelial cells. Am. Rev. Respir. Cell Mol. Biol. in press.

10. Liu, P. V. 1966. The role of various fractions of Pseudomonas aeruginosa in its pathogenesis. III. Identity of the lethal toxins produced in vitro and in vivo. J. Infect. Dis. 116:481-489.

11. Jackowski, J. T., Z. Szepfalusi, D. A. Wanner, Z. Seybold, M. W. Sielczak, I. T. Lauredo, T. Adams, W. M. Abraham, and A. Wanner. 1991. Effects of $P$. aeruginosa-derived bacterial products in tracheal ciliary function: role of $\mathrm{O}_{2}$ radicals. Am. J. Physiol. 260:L61-L67.

12. Cesarone, C. F., C. Bolognesi, and L. Santi. 1979. Improved microfluorometric DNA determination in biological material using 33258 Hoechst. Anal. Biochem. 100:188-197.

13. McFaul, S. J. 1990. A method for isolating neutrophils from moderate volumes of human blood. J. Immunol. Methods. 130:15-18.

14. Zigmond, S. H., and J. G. Hirsh. 1987. Leukocyte locomotion and chemotaxis. New methods of evaluation, and demonstration of cell-derived chemotactic factor. J. Exp. Med. 173:387-410.

15. Fontán, P. A., C. R. Amura, V. E. Garcia, M. C. Cerquetti, and D. O.
Sordelli. 1992. Preliminary characterization of Pseudomonas aeruginosa peptide chemotactins for polymorphonuclear leukocytes. Infect. Immun. 60:2465-2469.

16. Ras, G., R. Wilson, H. Todd, G. Taylor, and P. Cole. 1990. Effect of bacterial products on neutrophil migration in vitro. Thorax. 45:276-280.

17. Sordelli, D. O., M. C. Cerquetti, A. M. Hooke, and J. A. Bellanti. 1985. Effects of chemotactins released by Staphyloccocus aureus and Pseudomonas aeruginosa on the murine respiratory tract. Infect. Immun. 49:265-269.

18. Nicas, T. I., and B. H. Iglewski. 1985. The contribution of exoproducts to virulence of Pseudomonas aeruginosa. Can. J. Microbiol. 31:387-392.

19. Woods, D. E., and B. H. Iglewski. 1983. Toxins of Pseudomonas aeruginosa: new perspectives. Rev. Infect. Dis. 5:S715-S722.

20. Kharazmi, A., Z. Bibi, H. Nielsen, N. Høiby and G. Döring. 1989. Effects of Pseudomonas aeruginosa rhamnolipid on human neutrophil and monocyte function. Acta Pathol. Microbiol. Immunol. Scand. 97:1068-1072.

21. Dahinden, C., C. Galanos, and J. Fehr. 1983. Granulocyte activation by endotoxin. 1. Correlation between adherence and other granulocyte functions and role of endotoxin structure on biologic activity. J. Immunol. 130:857-862.

22. Stiver, H. G., K. Zachidniak, and D. P. Speert. 1988. Inhibition of polymorphonuclear leukocyte chemotaxis by the mucoid exopolysaccharide of Pseudomonas aeruginosa. Clin. Invest. Med. 11:247-252.

23. Carré, P. C., R. L. Mortenson, T. E. J. King, N. P. W., C. L. Sable, and D. W. H. Riches. 1991. Increased expression of the interleukin-8 gene by alveolar macrophages in idiopathic pulmonary fibrosis. A potential mechanism for the recruitment and activation of neutrophils in lung fibrosis. J. Clin. Invest. 88:1802-1810

24. Aduan, R. P., and H. Y. Reynolds. 1979. The importance of cell-mediated responses to Pseudomonas infections. In Pseudomonas Aeruginosa Clinical Manifestations of Infection and Recent Therapy. I. R. G. Rogett, editor. Academic Press, Inc., New York. 65-89.

25. Rendell, N. B., G. W. Taylor, M. Somerville, H. Todd, R. Wilson, and P. J. Cole. 1990. Characterisation of Pseudomonas rhamnolipids. Biochim. Biophys. Acta. 1045:189-193.

26. Levine, S. J., P. Larivee, C. Logun, and J. H. Shelhamer. 1992. Human bronchial epithelial cells secrete cytokines in response to IL-1 $\beta$, but not endotoxin: differential inhibition by dexamethasone. Am. Rev. Respir. Dis. 145:A361 (Abstr.).

27. Strieter, R. M., S. W. Chensue, M. A. Basha, T. J. Standiford, J. P. Lynch, M. Baggiolini, and S. L. Kunkel. 1990. Human alveolar macrophage gene expression of interleukin- 8 by tumor necrosis factor- $\alpha$, lipopolysaccharide, and interleukin-1 B. Am. J. Respir. Cell Mol. Biol. 2:321-326.

28. Standiford, T. J., S. L. Kunkel, M. A. Basha, S. W. Chensue, J. P. Lynch III, G. B. Toews, J. Westwick, and R. M. Strieter. 1990. Interleukin-8 gene expression by a pulmonary epithelial cell line. A model for cytokine networks in the lung. J. Clin. Invest. 86:1945-1953.

29. Lethem, M. I., S. L. James, and C. Marriott. 1990. The role of mucous glycoproteins in the rheologic properties of cystic fibrosis. Am. Rev. Respir. Dis. 267:1947-1951. 